\title{
Gluten enteropatisinin nadir ve cerrahi ile tanı konan komplikasyonu: Enteropati ilişkili T-hücreli lenfoma
}

\author{
A rare complication of gluten enteropathy diagnosed with surgery: Enteropathy associated T-cell lymphoma
}

Ilhan DOLAȘIK ${ }^{1}$, Hakan UZUNOĞLU², Selman ÇINAR², Selçuk Yusuf ŞENER ${ }^{1}$, Mehmet Zeki AYDIN ${ }^{1}$, Koray ÇELEBI ${ }^{1}$, Ömer ŞENTÜRK ${ }^{3}$, Sadettin HÜLAGU³

Kocaeli Universitesi Tıp Fakültesi ${ }^{1}$ Iç Hastalıkları Anabilim Dalı, ${ }^{2}$ Genel Cerrahi Anabilim Dalı, ${ }^{3}$ Gastroenteroloji Bilim Dalı, Kocaeli

Gluten enteropatisinin ileri dönemdeki iyi bilinen komplikasyonlarindan biri enteropati ilişkili lenfomadır. Hastalığın tedavisinde ve lenfoma gelişiminden korumada, gluten içeren gıdaların, ömür boyunca diyetten uzaklaştırılmaları gerekir. Glutensiz diyet sonrası, hastaların çoğunda klinik düzelme görülür ve intestinal mukozal yapı normale döner. Düzelmeyen az sayıdaki hastada, refrakter hastalık düşünülür; altta yatan bir jejunoileitis (ülseratif jejunit) veya lenfoma olabilir. Bu nedenle biz de gluten enteropatisi tanısı konan ve diyete önce cevap verip sonrasinda refrakter olan, çift balon enteroskopide jejunal kitle olduğunu saptadığımız ve cerrahi rezeksiyon sonrası enteropati ilişskili T hücreli lenfoma tespit ettiğimiz olgumuzu sunmak istedik. $\mathrm{Bu}$ vaka bize endoskopik tetkiklerle malign görünümlü kitle lezyonu tespit edilse dahi özellikle ülser ve erozyonların varlığında inflamatuvar değişikliklerin etkisi ile alınan biyopsilerde neoplastik hücrelerin tanımlanamayabileceğini göstermiştir. Bu vakada olduğu gibi şiddetle malignite düşünülen vakalarda cerrahi ile hem tanı konabilir hem de tedavi sağlanabilir.

Anahtar kelimeler: Gluten enteropatisi, T hücreli lenfoma, endoskopi

\section{GİRIS}

Gluten enteropatisi (GE) genetik yatkınlığı olan bireylerde diyetteki glutene karşı artmış immunolojik cevabın görüldügüu, hedef organin ince barsak olduğu bir hastalıktır (1). Esas etkilenen organ ince barsak olmasına rağmen GE'si multisistemik bir hastalıktır (2). GE'li bireylerde özofagus, ince ve kalın barsak kanserlerinin görülme sılklı̆ı normal bireylere göre artmıştır $(3,4)$. Intestinal lenfoma sıklığı ise normal bireylere göre 50 kat artmıştır (2). GE'li hastalarda lenfoma gelişiminin değerlendirilmesi güç olmakla birlikte bu hastalarda lenfoma sıklığ1 \%8-10 arasında bulunmuştur (5). GE'de intraepitelyal lenfositler CD3 ve CD8 eksprese ederken glutensiz diyete refrakter GE'de intraepitelyal lenfositler sadece CD3 eksprese ederler. Refrakter GE (özellikle tip 2) kötü prognoza sahip olup, lenfoma ile ilişkili olduğu düşünülmektedir (6-7). Bu yazıda GE tanısıyla takip edilen ve tanısı ancak cerrahi ile konulabilen enteropati ilişkili lenfoma olgusunu yayınlamayı amaçladik.

\section{OLGU}

Kırkdört yaşında bayan hasta Haziran 2008'de ishal ve karın ağnısı şikayetleri nedeniyle Kocaeli Üniversitesi Tıp Fakültesi
One of the well-known complications of gluten enteropathy in the advanced stage is lymphoma-associated enteropathy. In the treatment of the disease and prevention of lymphoma development, gluten-containing foods must be removed from the diet on a lifelong basis. In the majority of patients, clinical improvement is seen and intestinal mucosal architecture normalizes after a gluten-free diet. Refractory disease is considered in a small number of patients without recovery; underlying jejunoileitis (ulcerative jejunitis) or lymphoma may exist. Accordingly, we want to report our case with gluten enteropathy who initially responded to the diet but later become refractory. In this case, we detected a jejunal mass with double balloon enteroscopy, and enteropathyassociated T-cell lymphoma was diagnosed after surgical excision. This case showed that neoplastic cells may not be defined in biopsies taken under the impact of inflammatory changes, especially in the presence of ulcer and erosions, even though a malignant-looking mass lesion was detected in endoscopic examinations. As in this case, both diagnosis and treatment can be achieved with surgery in patients with strongly suspected malignancy.

Key words: Gluten enteropathy, T-cell lymphoma, endoscopy

Gastroenteroloji Polikliniği'ne başvurdu. Endoskopik ve serolojik tetkiklerle GE tanısı konan hastanın diyet tedavisi ile birlikte semptomları tamamen düzeldi. Hasta Ocak 2009'da birkaç haftadır tekrarlayan ve gün geçtikçe artan bulantı, yemeklerden sonra sindirilmemiş gıdaları içerir tarzda kusma, göbek etrafinda ağnı ve kilo kaybı şikayetleriyle kliniğimize başvurdu. Soy geçmişinde herhangi bir özellik yoktu. Hastanın fizik muayenesinde kan basinc1: 110/70 mmHg, nabız: 86/dk, ateş: $37.8^{\circ} \mathrm{C}$ saptandi; batında rebound ve defansın eşlik etmediği yaygın hassasiyet tespit edildi. Diğer sistem muayeneleri normaldi. Hastanın laboratuvar bulguları GE ile uyumlu idi (Tablo 1). Ayakta direkt karın grafisinde önemli bir bulgu saptanmayan hastanın çekilen batın tomografisinde jejenum anslarında kalınlaşma, mezenterik ve paraaortik lenfoadenopatiler tespit edildi. Hastada ön tanı olarak malignite düşünülerek oral yoldan çift balonlu enteroskopi (ÇBE) yapıldı. ÇBE'de postbulber bölgede mukoza ödemli ve pililerde taraklanma izlendi. Jejenal anslarda lümeni çepeçevre saran ve daraltan mukozal ödem, düzensizlik, granülerite ve fragilite izlendi (Resim 1). Alınan biyopsilerde malignite bulgusuna rastlanmadi. 


$\begin{array}{lc}\text { Tablo 1. Hastanın bașvuru anindaki laboratuvar bulguları } \\ \text { Glukoz (mg/dl) } & 71 \\ \text { Kreatinin (mg/dl) } & 0,4 \\ \text { AST (IU/ml) } & 50 \\ \text { ALT (IU/ml) } & 27 \\ \text { LDH (IU/ml) } & 495 \\ \text { ALP (IU/ml) } & 87 \\ \text { Total Protein (g/dl) } & 6,5 \\ \text { Albümin (g/dl) } & 3,1 \\ \text { Hemoglobin (g/dl) } & 10,2 \\ \text { Anti-Endomisyum IgA } & \text { Pozitif (+) } \\ \text { Anti Doku Transglutaminaz IgA } & \text { Pozitif (+) }\end{array}$

Hastanın kısmi obstruktif semptomlarının varlığı, ÇBE'deki görünümünün malignite düşündürmesi ve batın tomografisinde mezenterik ve paraaortik lenfadenopati varlığı nedeniyle tanısal ve terapötik amaçlı laparotomi yapıldı. Tümöral kitlenin jejenumdan kaynaklandığı saptandı ve kısmi intestinal rezeksiyon ve uç uca jejunojejunostomi yapıldı. $45 \mathrm{~cm}$ 'lik jejunal ans çıkarıldı. Rezeksiyonu yapılan örneğin patolojik incelemesinde normal mukozanın yanı sıra lamina propriada, daralmış stoplazmalı, oval, yuvarlak ve yer yer ikili çoklu nukleuslu atipik hücrelerin olduğu, bunların submukozayı ve muskularis propria'yı yaygın olarak infiltre ettiği ve CD3 ve CD30 immünohistokimyasal boyanması pozitif olduğu, atipik lenfosit infiltrasyonu izlendi (Resim 2,3). Çıkarılan lenf nodlarında da malign infitrasyon tespit edildi. Patolojik tanı, enteropati ilişkili T hücreli lenfoma (ETL) geldi. Cerrahi sonrası dönemde, ek problem gelişmedi ve kemoterapi planlanarak hasta taburcu edildi.

\section{TARTIȘMA}

GE, histolojik olarak villus atrofisi, kript hiperplazisi ve intraepitelyal lenfositoz ile karakterize malabsorbsiyonun görüldüğü glutene duyarlı bir enteropatidir (8). Tanı semptom ve bulgular (karın ağrısı, şişkinlik, anemi, kilo kaybı, osteoporoz gibi) eşliğinde serolojik (anti endomisyum IgA-IgG, anti doku transglutaminaz IgA-IgG gibi) ve histopatolojik bulgulara dayanılarak konulur (9). Olgumuz serolojik ve histopatolojik olarak GE ile uyumlu bulgulara sahipti. Glutensiz diyete başlangıç dönemde iyi yanıt vermesi GE tanısını doğrulamıştır.

GE'sinde hem B hücreli hem de T hücreli intestinal lenfoma gelişebilmekle birlikte sıklıkla görülen T hücreli lenfomadır. $\mathrm{Bu}$ lenfomalar tüm gastrointestinal lenfomaların \%5'ini oluşturur ve komplikasyonlu GE zemininde gelişir (10). Çoğunlukla jejenumda görülebilirse de ince barsak diğer kısımları, mide ve kolonda da ortaya çıkabilmektedir (11). Enteropati ilişkili lenfomalar genellikle ülserasyon veya obstrüktif lezyonlar şeklinde tespit edilir (10). Diğer taraftan nadir olarak intestinal bulgu olmaksızın dalak ve karaciğer tutulumu ile karşımıza çıkabilir (12). Olgumuzda lezyonlar jejenumda obstrüktif karakterde izlenmiştir.

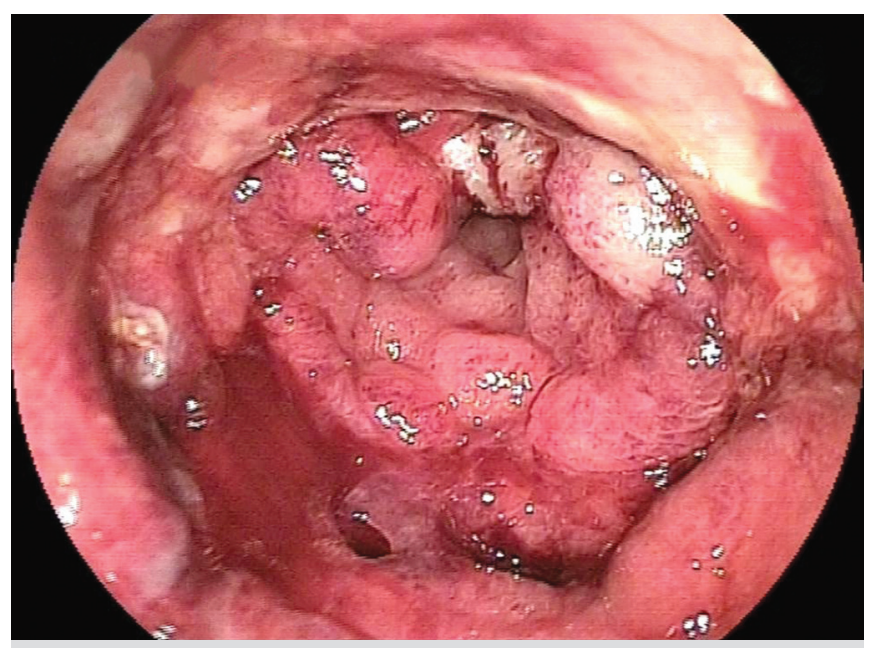

Resim 1. Jejunal anslarda lümeni çepeçevre saran, mukozal düzensizlik, granülarite, frajilite. Endoskopik görünüm.

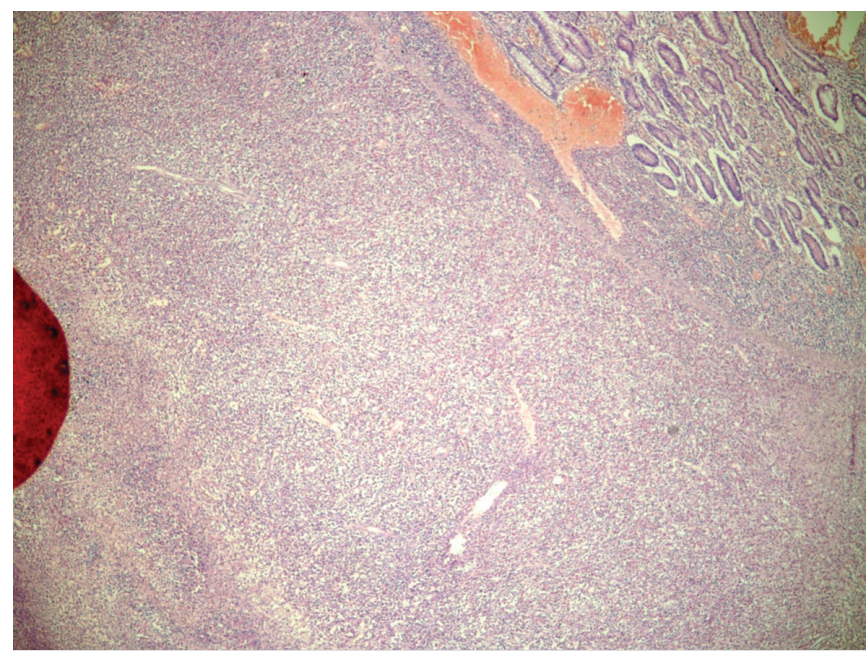

Resim 2. Normal mukozanın komşuluğunda infiltre görünüm. (HE x 20)

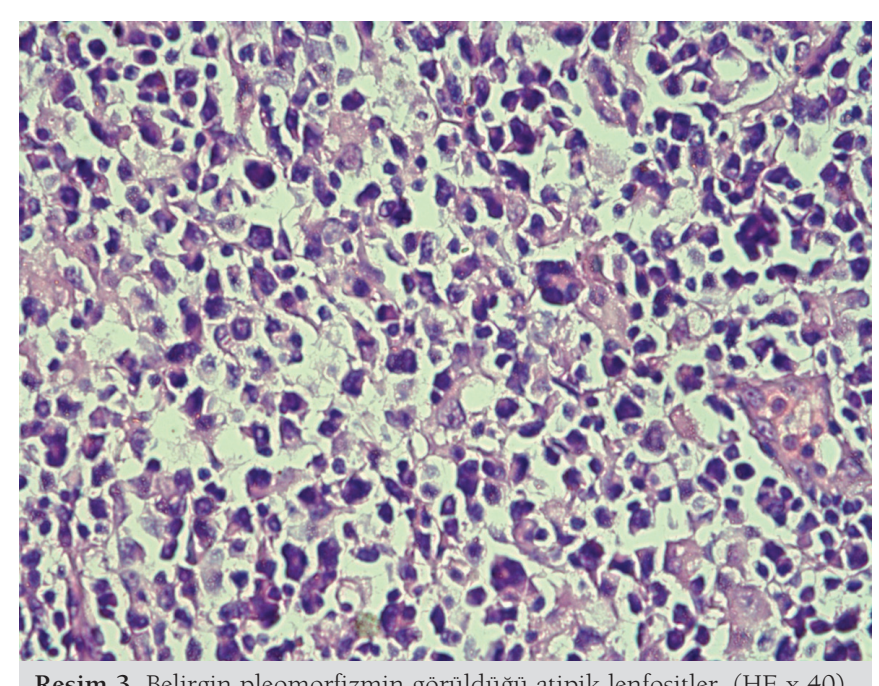

Resim 3. Belirgin pleomorfizmin görüldüğü atipik lenfositler. (HE x 40) 
GE'nin non-malign komplikasyonları infertilite, romatizmal bozukluklar, vitamin D ve kalsiyum metobolizması bozuklukları, depresyon, epilepsi, karpal tunel sendromu ve myopatidir (13). GE'nin ülseratif jejuno ileit, striktür ve enteropati ilişkili lenfoma gibi diğer önemli ve ciddi komplikasyonlarının tespitinde kullanılabilecek öncelikli tetkikler magnetik rezonans enteroklizis, bilgisayarlı tomografi enteroklizistir. Özellikle karın ağrısı, anemi, kilo kaybı, ishal gibi yakınmaları olan hastalarda ÇBE de öncelikli tetkikler arasında düşünülmelidir (14). Hastamızda sıkı diyete rağmen karın ağrısı, bulantı, kusma ve kilo kaybı olması nedeniyle ÇBE öncelikle yapılmıştır.

Kuvvetli lenfoma şüphesine rağmen, ince barsakta ülserler erezyonların varlığında enflamatuvar değişikliklere bağlı olarak neoplastik hücrelerin tanınmasının zorluğu nedeniyle endoskopik biyopsilerle tanıya ulaşılamıyabilir (15). Bu durumda laporoskopik tam kat intestinal biyopsileri de içeren invaziv tanı yöntemlerine başvurmak gerekebilir (16). Ancak buna rağmen tanı konulamayabilir. Bizim olgumuzda endoskopik biyopsilerle tanı konulamamış olup, ancak cerrahi mater- yalle tanı konabilmiştir. Intestinal lenfoma tanısı konduğunda sistemik kemoterapi öncesinde (kemoterapi sırasında gelişebilecek barsak perforasyonunu önlemek için) debulking cerrahisi uygulanmalıdır (14). Bütün bunlara rağmen hastalığın prognozu kötüdür. ETL neredeyse tamamı yüksek grade histolojiye sahiptir ve 5 ylllık yaşam süresi yaklaşık \%10 kadardır (16). Cerrahi sonrası sistemik kemoterapi başlanmasına rağmen hastamızın durumu gün geçtikçe kötüye gitmektedir.

Çoğu ETL olgusunda lezyonun jejenumda (11) bulunmasından dolayı tanı endoskopik yöntemler (ÇBE) veya cerrahi olarak konulabilmektedir. Olgumuz GE'nin özellikle alarm semptomları olan hastalarda ÇBE'nin önemini bir kez daha göstermiştir. Her ne kadar lezyon ÇBE ile tespit edilse de endoskopik biopsilerle tanıya ulaşılamayabilir. Bu durumlarda kuvvetli malignite şüphesi olan hastalarda laparoskopik tam kat intestinal biyopsi yapılmalıdır. Buna rağmen malignite tanısı konulamayan hastalarda intestinal kitle, alarm semptomlarının ve abdominal lenf nodlarının mevcudiyetinde cerrahi düşünülmelidir.

\section{KAYNAKLAR}

1. American Gastroenterological Association medical position statement: Coeliac sprue. Gastroenterology 2001;120:1522-5.

2. Leeds JS, Hopper AD, Sanders DS. Coeliac disease. Br Med Bull 2008;88: 157-70.

3. Solaymani-Dodaran M, West J, Logan RF. Long-term mortality in people with celiac disease diagnosed in childhood compared with adulthood: a population- based cohort study. Am J Gastroenterol 2007;102:864-70.

4. Peters U, Askling J, Gridley G, et al. Causes of death in patients with coeliac disease in a population-based Swedish cohort. Arch Intern Med 2003;163:1566-72

5. Freeman HJ. Neoplastic disorders in 100 patients with adult celiac disease. Can J Gastroenterol 1996;10:163-6.

6. Daum S, Cellier C, Mulder CJ. Refractory coeliac disease. Best Pract Res Clin Gastroenterol 2005;19:413-24.

7. Cellier C, Delabesse E, Helmer C, et al. Refractory sprue, coeliac disease, and enteropathyassociated T-cell lymphoma. French Coeliac Disease Study Group. Lancet 2000;356:203-8.

8. Patey-Mariaud de Serre N, Cellier C, Jabri B, et all. Distinction between coeliac disease and refractory sprue: a simple immunohistochemical method. Histopathology 2000;37:70-7.

9. Rodrigo L. Celiac disease. World J Gastroenterol 2007;12:6585-93.

10. Brousse N, Meijer JW. Malignant complications of coeliac disease. Best Pract Res Clin Gastroenterol 2005;19:401-12.

11. Catassi C, Bearzi I, Holmes GK. Association of celiac disease and intestinal lymphomas and other cancers. Gastroenterology 2005;128(4 Suppl 1):S79-86.

12. Freeman HJ. Fulminant liver failure with necrotizing foci in the liver, spleen and lymph nodes in celiac disease due to malignant lymphoma. Can J Gastroenterol 1996;10:225-9.

13. Holmes GK. Non-malignant complications of coeliac disease. Acta Paediatr Suppl 1996;412:68-75

14. Van Weyenberg SJB, Jarbandhan SVA, Mulder CJJ, et al. Double Balloon Endoscopy in Celiac Disease. Tech Gastrointest Endosc 2008;10:87-93.

15. Freeman HJ, Weinstein WM, Shnitka TK, et al. Primary abdominal lymphoma. Presenting manifestation of celiac sprue or complicating dermatitis herpetiformis. Am J Med 1977;63:585-94.

16. Egan LJ, Walsh SV, Stevens FM, et al. Celiac-associated lymphoma. A single institution experience of 30 cases in the combination chemotherapy era. J Clin Gastroenterol 1995;21:123-9. 